\title{
Response of Streamflow to Climate Changes within a Mountainous Catchment
}

\author{
Fan Ping ${ }^{1}$ and Qiang Liu $^{1, *}$ \\ ${ }^{1}$ Beijing Normal University, Haidian Qu, Beijing Shi, China
}

\begin{abstract}
Climate changes combined with alteration in landuse, alter the hydrological processes and has increased flood risk in urban area. A better understanding of how the climate alter streamflow in the catchment of city surrounding area would help to reduce urban flood risk. In the present study, we assessed the response of streamflow to climate changes in a mountainous catchment of city surrounding area, Dashi River catchment, China. The Distributed Hydrology-Soil-Vegetation Model (DHSVM) was used to simulate the streamflow in different scenarios of climate and landuse changes. Results showed that: (i) DHSVM showed suitable performance in terms of calibration and validation periods; and (ii) Streamflow increased/decreased with increasing/decreasing precipitation, while decreased with increasing air temperature. And the increases or decreases in precipitation can directly lead to the significant corresponding directional changes in the streamflow, especially in summer season. The results would help to understand streamflow response to changes in climate and landuse, and help to reduce the flood risk in the urban regions.
\end{abstract}

\section{Introduction}

Climate combined with landuse changes has dramatically altered the hydrological processes (Chien et al., 2013; Niraula et al., 2015). Climate changes/variability resulting in temperature rises, changes in precipitation and altering the evapotranspiration, thereby affecting the volume, peak rate, and timing of streamflow (Niraula et al., 2015; Pourmokhtarian et al., 2016). Therefore, with the intensification of global warming, extreme hydrological events are generally showing an increasing trend (Goswami et al., 2006), which have led to extreme hydrological disasters occur frequently, e.g., flood, drought (Kourgialas et al., 2015; Zhang et al., 2015). Especially, in the catchments of city surrounding area where rapidly urbanization has increased the impermeable area and weakened the capability of water storage, that resulted in an increasing trend in extreme hydrological events and a more significant threaten to urban water security (Peng et al., 2015; Bellu et al., 2016). Consequently, our objectives are: (i) to explore the parameter sensitivity, and assess the performance of DHSVM in a small mountainous catchment of city surrounding area; and (ii) to estimate the streamflow response to climate and landuse changes scenarios in the Dashi River catchment, China. The results should help to understand the

\footnotetext{
* Corresponding author: luiqiang@bnu.edu.cn
} 
response of streamflow to climate changes in the catchment of city surrounding area and help to address the flood risk in the city.

\section{Study site and methodology}

\subsection{Study site}

Dashi River is a tributary of Juma River in the Haihe River Basin, which originates from Xiayunling of Fangshan District in Beijing, China. The total length of Dashi River is $129 \mathrm{~km}$, and the catchment area is $1,280 \mathrm{~km}^{2}$. Dashi River catchment is located in the southwest of Beijing. Dashi River Catchment belongs to semi-humid continental monsoon climate, which is hot and rainy in summer, cold and dry in winter. The mean annual temperature is $9-1{ }^{\circ} \mathrm{C}$, while the mean annual precipitation (1956 to 2004) is $587.6 \mathrm{~mm}$ and concentrated in summer (June to August). The upper catchment, the mountainous area above hydrological station, was selected as a study area (Figure 1) which total area is $664 \mathrm{~km}^{2}$. Due to influenced by extreme hydrological event, Dashi River catchment have suffered an extraordinary rainstorm in July 21, 2012, which was the strongest rainstorm in northern China since detailed meteorological records began in 1951 and also caused the greatest number of casualties and economic losses (Su et al., 2015).

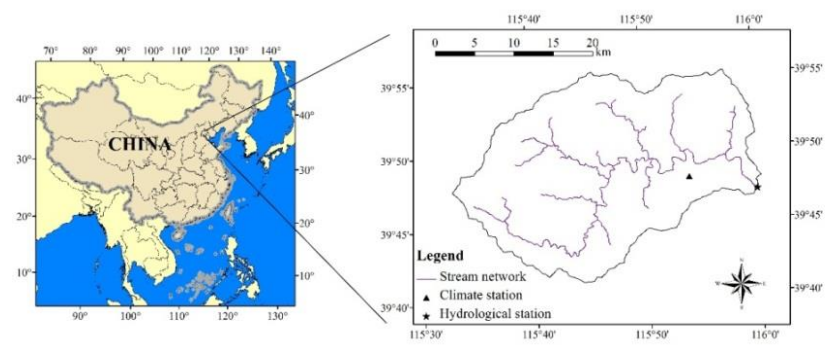

Fig. 1. Geographical location of Dashi River catchment, China.

\subsection{Methodology and data description}

The Distributed-soil-vegetation model (DHSVM) is a physically based distributed hydrologic model developed for mountainous watersheds (Wigmosta et al., 1994), which has been widely used to assess the impacts of climate changes on hydrological processes (Wigmosta et al., 1994; Safeeq and Fares, 2012; Cuo et al., 2009; Dickerson-Lange and Mitchell, 2014). One-factor-at-a-time (OFAT) were used to analyze sensitive parameters in DHSVM while examined using Bias and root mean square error (RMSE); and the Nash-Sutcliffe efficiency coefficient (NSE) (Nash and Sutcliffe, 1970) and the coefficient of determination $\left(\mathrm{R}^{2}\right)$ were used to evaluate the model performance at simulating.

To construct the DHSVM in Dashi River catchment, a model database was compiled using meteorological data (e.g., precipitation, wind speed, maximum and minimum temperature) and topographical data (consisting of a digital elevation map, landuse and soil map).The Meteorological data, including precipitation, temperature, wind speed, used for DHSVM calibration and validation were taken from Xiayunling climate station (Figure 1).

The DHSVM requires the digital elevation model (DEM), soil and vegetation maps to simulate the hydrological cycle. The DEM was obtained from USGS/NASA Shuttle Radar Topography Mission 
(SRTM) data; the soil map (100 m resolution) was adapted from the world soil database (Harmonized World Soil Database). The vegetation map (100 m resolution) was generated based on the land cover data of Beijing in 1980 provided by Data Center for Resources and Environmental Sciences, Chinese Academy of Sciences. Furthermore, 8 climate change scenarios were used to assess the impacts of climate changes on streamflow with the precipitation changes of $+10 \%$ (scenario 1 ), $+20 \%$ (scenario 2 ), $-10 \%$ (scenario 3), and $-20 \%$ (scenario 4), and air temperature changes increased $1{ }^{\circ} \mathrm{C}$ (scenario 5), $2{ }^{\circ} \mathrm{C}$ (scenario 6), $3{ }^{\circ} \mathrm{C}$ (scenario 7), and $4{ }^{\circ} \mathrm{C}$ (scenario 8).

\section{Results}

\subsection{Parameter sensitivity and model validation}

In the sensitivity analysis, 13 soil parameters and 20 vegetation parameters of the DHSVM underwent sensitivity analyses to determine the optimal model parameters. Among these parameters, the maximum infiltration, porosity, field capacity and wilting point are the most sensitive soil parameters; while leaf area index and vegetation height are the most sensitive vegetation parameters. DHSVM was manually calibrated taking into account daily and monthly streamflow by adjusting these sensitive parameters.

During both the calibration and validation periods, simulated daily and monthly streamflow agreed reasonably with the observed streamflow for both time steps (Figure 2), the NSE values for daily streamflow simulations during calibration and validation period were 0.62 and 0.71 , respectively; and were 0.79 and 0.88 of monthly time step for the three-year calibration and validation, respectively. The $\mathrm{R}^{2}$ of monthly time step reached up to 0.84 and 0.89 for the calibration and validation period, respectively.
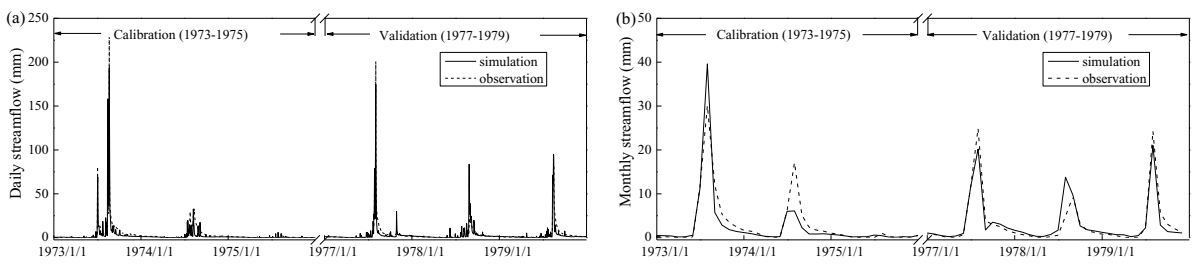

Fig. 2. Observed and simulated streamflow during the calibration (Jan. 1, 1973-Dec. 31, 1975) and validation (Jan. 1, 1977-Dec. 31, 1979) period: (a) daily streamflow; (b) monthly streamflow.

\subsection{Response of streamflow to climate changes}

Figure 3 showed the response of streamflow to climate changes: (i) as expected, the mean annual streamflow steadily increased (or decreased) with precipitation increasing (or decreasing); (ii) the precipitation scenarios have notable differences from the baseline, especially in the summer season; and (iii) the mean annual streamflow slightly decreased with air temperature increased. 

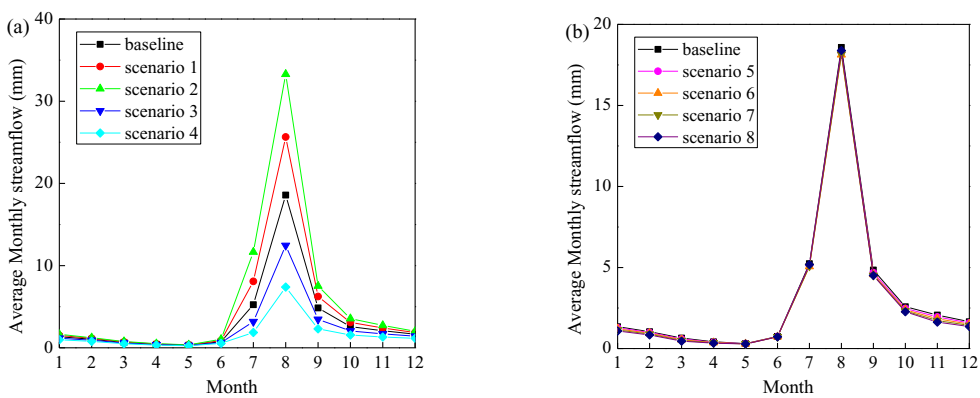

Fig. 3. Simulated streamflow in different climate change scenarios: (a) streamflow changed with precipitation change scenarios 1 to 4 correspond to the precipitation changed $+10 \%,+20 \%,-10 \%$ and $-20 \%$; and (b) streamflow changed with air temperature scenarios, scenario 5 to 8 correspond to the air temperature increased $1{ }^{\circ} \mathrm{C}, 2{ }^{\circ} \mathrm{C}, 3{ }^{\circ} \mathrm{C}$ and $4{ }^{\circ}$ Increase in precipitation contribute magnitude to changes in streamflow, e.g., annual streamflow increased about $32.73 \%$ and $68.18 \%$ with precipitation increased $10 \%$ and $20 \%$, respectively; while it decreased about $-28.69 \%$, and $-52.17 \%$ when precipitation decreased $-10 \%$ and $20 \%$, respectively. Similar results for the changes in streamflow also can be found in maximum changes of streamflow. For air temperature, streamflow will decrease with increase in air temperature due to its complex effects on hydrological processes, and interestingly sensitivity of streamflow reduced with the increase in air temperature, e.g., $1^{\circ} \mathrm{C}$ warming will cause streamflow increase $-2.79 \%$ in scenarios, while it just will cause an increase in streamflow with -2.01 , -1.13 and $-0.19 \%$, between scenario 5 and 6 , scenarios 6 and 7 , and scenarios 7 and 8 , respectively.

\section{Discussion}

Climate changes/ variability (e.g., temperature rises and changes in precipitation) have significant impacts on regional streamflow (Chen et al., 2006; Huo et al., 2008). The Haihe River Basin have been intensified by the decreasing precipitation and steadily declining streamflow due to climate change and increasing human activity during the past decades (Yang and Tian, 2009). Bao et al (2011) concluded the streamflow would increase as precipitation increased but would decrease as temperature increased, which is similar with our result. Results of sensitivity analysis showed that changes in streamflow are more sensitive to increase in precipitation in contrast with decrease in precipitation, e.g, streamflow can increase $32.73 \%$ or decrease $28.69 \%$ with $10 \%$ increase or decrease in precipitation. Streamflow response to changes in precipitation is consistent with results provided by Qi et al. (2009). Interestingly, increase rate of streamflow decreased with increase in air temperature, e.g., streamflow was reduced by $2.01 \%$ when $1{ }^{\circ} \mathrm{C}$ increased compared with baseline condition, while it was reduced by $1.13 \%$ when 2 ${ }^{\circ} \mathrm{C}$ increased compared with $1{ }^{\circ} \mathrm{C}$ increase. The reasons for that mainly lay that streamflow will be reduced by increase in evaporation when other meteorological variables keep in normal condition. In fact, changes of streamflow resulted from increasing air temperature reflected complex interaction between meteorological variable. Especially, explanations for "evaporation paradox" have enhanced the understanding of hydrological mechanism for increasing air temperature (Liu and McVicar, 2012; Szilagyi, et al., 2017).

\section{Conclusion}

This study investigated the response of streamflow to the changes in climate and landuse within a 
mountainous catchment of city surrounding area, Dashi River catchment. The DHSVM have been established in the study area, and run in different climate and landuse change scenarios. Several conclusions can be drawn as followed:

(i) The parameters sensitivity analyze of DHSVM in this area have been examined. And the most sensitive soil parameters are the maximum infiltration, porosity, field capacity and wilting point, while leaf area index and vegetation height are the most sensitive vegetation parameters. The DHSVM was suitable performance to simulate the streamflow with NSE and $\mathrm{R}^{2}$ values of 0.88 and 0.89 in monthly scale, respectively.

(ii) Changes of streamflow was more sensitive to increasing in precipitation than that resulted from the decrease in precipitation. For air temperature, streamflow decrease with increase in air temperature, and increase rate in streamflow presented decreasing trend with the increase in air temperature, streamflow was reduced by $2.01 \%$ when $1{ }^{\circ} \mathrm{C}$ increase compared with baseline condition, while it was reduced by $1.13 \%$ in $2{ }^{\circ} \mathrm{C}$ increase when compared with $1{ }^{\circ} \mathrm{C}$ increase.

This research was supported by the National key research and development program (2016YFC0500402, 2018ZX07110001), the National Natural Science Foundation of China (no. 51579008), the Interdiscipline Research Funds of Beijing Normal University, and the Open Research Fund Program of Beijing Climate Change Response Research and Education Center (Beijing University of Civil Engineering and Architecture). Thanks to the National Meteorological Information Center, China Meteorological Administration, for offering the meteorological data.

\section{Reference}

Bao, Z.X., Zhang, J.Y., Liu, J.F., Wang, G.Q., Yan, X.L., Wang, X.J., Zhang, L.R., 2012. Sensitivity of hydrological variables to climate change in the Haihe river basin, china. Hydrol Process 26, 2294-2306.

Chen, Y.N., Takeuchi, K., Xu, C.C., Chen, Y.P., Xu, Z.X., 2006. Regional climate change and its effects on river runoff in the Tarim basin, china. Hydrol Process 20, 2207-2216.

Chien, H.C., Yeh, P.J.F., Knouft, J.H., 2013. Modeling the potential impacts of climate change on streamflow in agricultural watersheds of the Midwestern United States. J Hydrol 491, 73-88.

Cuo, L., Lettenmaier, D.P., Alberti, M., Richey, J.E., 2009. Effects of a century of land cover and climate change on the hydrology of the Puget Sound basin. Hydrol Process 23, 907-933.

Goswami, B.N., Venugopal, V., Sengupta, D., Madhusoodanan, M.S., Xavier, P.K., 2006. Increasing trend of extreme rain events over India in a warming environment. Science 314, 1442-1445.

Huo, Z.L., Feng, S.Y., Kang, S.Z., Li, W.C., Chen, S.J., 2008. Effect of climate changes and water-related human activities on annual stream flows of the Shiyang river basin in and north-west China. Hydrol Process 22, 3155-3167.

Kourgialas, N.N., Dokou, Z., Karatzas, G.P., 2015. Statistical analysis and an modeling for predicting hydrological extremes under climate change scenarios: The example of a small Mediterranean agro-watershed. J Environ Manage 154, 86-101.

Liu, Q., McVicar, T.R., Yang, Z.F., Donohue, R.J., Liang, L.Q., Yang, Y.T., 2016. The hydrological effects of varying vegetation characteristics in a temperate water-limited basin: Development of the dynamic budyko-choudhury-porporato (dbcp) model. J Hydrol 543, 595-611. 
Nash, J.E., Sutcliffe, J.V., 1970. River flow forecasting through conceptual models Part I - A discussion of principles. J Hydrol 10, 282--290.

Niraula, R., Meixner, T., Norman, L.M., 2015. Determining the importance of model calibration for forecasting absolute/relative changes in streamflow from LULC and climate changes. $J$ Hydrol 522, 439-451.

Peng, X.D., Shi, D.M., Guo, H.Z., Jiang, D., Wang, S.S., Li, Y.X., Ding, W.B., 2015. Effect of urbanisation on the water retention function in the three gorges reservoir area, China. Catena 133, 241-249.

Pourmokhtarian, A., Driscoll, C.T., Campbell, J.L., Hayhoe, K., Stoner, A.M., Adams, M.B., Fernandez, I., Burns, D., Mitchell, M.J., Shanley, J.B., 2016. Modeled ecohydrological responses to climate change at seven small watersheds in the northeastern U.S. Global Change Biology 2016.

Qi, S., Sun, G., Wang, Y., McNulty, S.G., Moore Myers, J.A., 2009. Streamflow response to climate and landuse changes in a coastal watershed in North Carolina. Transactions of the ASABE 52(3), 739-749.

Safeeq, M., Fares, A., 2012. Hydrologic effect of groundwater development in a small mountainous tropical watershed. J Hydrol 428, 51-67.

Su, Y., Zhao, F., Tan, L.Z., 2015. Whether a large disaster could change public concern and risk perception: A case study of the 7/21 extraordinary rainstorm disaster in Beijing in 2012. Nat Hazards 78, 555-567.

Szilagyi, J., Crago, R., Qualls, R., 2017. A calibration - free formulation of the complementary relationship of evaporation for continental - scale hydrology. Journal of Geophysical Research: Atmospheres 122(1), 264-278.

Wigmosta, M.S., Vail, L.W., Lettenmaier, D.P., 1994. A distributed hydrology-vegetation model for complex terrain. Water Resources Research 30, 1665-1679.

Yang, Y.H., Tian, F., 2009. Abrupt change of runoff and its major driving factors in Haihe River catchment, China. J Hydrol 374, 373-383.

Zhang, A., Zheng, C., Wang, S., Yao, Y., 2015. Analysis of streamflow variations in the Heihe river basin, northwest China: Trends, abrupt changes, driving factors and ecological influences. $J$ Hydrol Regional Studies 3, 106-124. 